\title{
Motives for Obtaining a Doctorate and Perceived Meaningfulness of Doctorates: A Comparison between Medicine and Life Sciences
}

Nurith Epstein ( $\nabla$ nurith.epstein@med.uni-muenchen.de)

Klinikum der Universitat Munchen

Johanna Huber

Institut für Didaktik und Ausbildungsforschung in der Medizin, Klinikum der Universität München (LMU)

Kathrin Redies

Institut für Didaktik und Ausbildungsforschung in der Medizin, Klinikum der Universität München (LMU)

Sonja Heuser

Institut für Didaktik und Ausbildungsforschung in der Medizin, Klinikum der Universität München (LMU)

Daniel Lachmann

Prorektorat für Studium und Lehre, Universität zu Köln

Research article

Keywords: medical doctorate, life sciences, motives for obtaining a doctorate, meaningfulness, early career researchers, academic research careers

Posted Date: April 27th, 2020

DOl: https://doi.org/10.21203/rs.3.rs-23494/v1

License: (9) (1) This work is licensed under a Creative Commons Attribution 4.0 International License. Read Full License 
1 Motives for Obtaining a Doctorate and Perceived Meaningfulness of Doctorates: A 2 Comparison between Medicine and Life Sciences

3

4 Authors: Nurith Epstein ${ }^{1}$, Johanna Huber ${ }^{1}$, Kathrin Redies ${ }^{1}$, Sonja Heuser ${ }^{1}$, Daniel Lachmann ${ }^{2}$

$5 \quad{ }^{1}$ Institut für Didaktik und Ausbildungsforschung in der Medizin, Klinikum der Universität

6 München (LMU)

$7 \quad{ }^{2}$ Prorektorat für Studium und Lehre, Universität zu Köln

8

9

10 Corresponding author:

11 Dr. Nurith Epstein

12 Institut für Didaktik und Ausbildungsforschung in der Medizin

13 Ludwig-Maximilians University Hospital Munich

14 Pettenkoferstr. 8a

1580336 Munich, Germany

16 Email: nurith.epstein@med.uni-muenchen.de 


\section{Abstract}

Background: In Germany, more than half of the students complete a doctorate in the life sciences and medicine. Thus the doctorate, which is supposed to pave the way for a research career, also seems to perform other functions. In medicine, there is a cliché that students earn doctorates for reasons of prestige but in the life sciences, there is an assumption that you will not succeed on the labor market without a doctorate. To date, we know little about the actual motives for earning a doctorate and its perceived meaningfulness after graduation.

Methods: Motives for obtaining a doctorate from both subject groups were analyzed using data from the E-Prom study $(\mathrm{N}=1518)$. For medicine, additional data from the Bavarian Graduate Study MediBAS ( $=570$ ) were analyzed. Qualitative interview data from the E-Prom study $(\mathrm{N}=28)$ were used to better understand the motives for obtaining a doctorate in their substance and to compare them with the retrospectively perceived meaningfulness.

Results: In medicine, the motives of "customariness" and feared "career disadvantages" predominate. Approximately half of the medical doctoral graduates had little or no interest to do research during or after the doctorate. In the life sciences, customariness and feared career disadvantages are important motives, too. However, research (career) interest also receives high and significantly higher approval than in medicine. Moreover, female medical graduates express significantly lower research and career motives; the latter also applies to the life sciences. The qualitative analyzes indicate a close connection between career paths and justifications of meaningfulness of the doctorate in the life sciences. In medicine, justifications of meaningfulness are closely related to initial motives for obtaining a doctorate. Hence, people who only pursued a doctorate to bear a title accordingly justified their doctorate's meaningfulness merely with its acquisition.

Conclusion: Our results stress the need for greater promotion of (academic) research careers among medical students, as well as the promotion of female careers in and outside of academic research. Further investigations are necessary to understand the exact mechanisms behind our results and to develop effective interventions.

Keywords: medical doctorate, life sciences, motives for obtaining a doctorate, meaningfulness, early career researchers, academic research careers 


\section{Background and Research Questions}

The doctorate is a prerequisite for an academic research career and is regarded as proof of qualification for independent research (1). Whereas in many countries the doctorate primarily serves as an entry to an academic career, in Germany the doctorate in many subject areas, in addition to being a qualification for an academic career, also serves as a springboard for a career in the private sector (1-3). This can be explained on the one hand by the large number of doctorates in Germany who exceed the number of available positions in academic research (2, 4), and on the other hand by special cultural aspects which make doctorates also desirable for certain career paths outside academia. When comparing the doctoral graduation rates with the available long-term positions in academic research, it follows that doctoral graduates (have to) leave academic research at various points in time. Since the proportion of early career researchers has risen while the proportion of professorships has dropped, the problem has worsened further (4). The proportion of professorships is just under 10 percent, the largest share of employees consists of academic staff on fixed-term and part-time contracts $(2,4)$. engaged in earning doctorates. As a result, the doctorate is even considered the standard degree in medicine. However, the data on the proportion of doctorates varies widely, with values between 60 and 80 percent (5), mostly in relation to individual institutions. It should be noted here that the professional doctorate does not exist in Germany, i.e., students do not automatically receive an MD (Doctor of Medicine) after completing their studies, but have to compile a thesis that leads to the title of "Dr.med.". Since the term "doctor" has become a synonym for the term "physician" in everyday language, there may be a fear among medical students that lacking the title of "Dr" might worry patients (6). In addition, a doctorate and postdoctoral lecture qualifications are often a prerequisite for higher positions/careers in (university) hospitals (5).

The doctorate rates are also high in the basic subjects of the life sciences (hereafter referred to as "life sciences"); in biology between 50 and 60 percent are stated $(7,8)$ and even 90 percent in chemistry (9). While a relatively high amount of life scientists initially remain in academic research as postdocs, a large proportion of medical doctoral graduates leave academic research $(2,3,10,11)$. This results in the often lamented shortage of physician/clinician scientists (12). Various factors are likely to contribute to this situation: the above-mentioned framework conditions of academic research careers, a lack of research interest, focus on patient care, and/or inadequate training in basic research methodology $(6,12,13)$. Since the collaboration between physician/clinician scientists with basic researchers is considered 
essential for the successful translation from "bench to bedside", the phenomenon is viewed critically (14).

Moreover, the overarching quality of medical doctoral theses has come in for massive criticism and has even gained international attention $(15,16)$. An impression is created that a majority of the medical students are pursuing doctorates to gain reputation based on the expectations of patients and colleagues respectively, and that scientific progress plays a minor role $(5,17,18)$. There already are initial empirical indications of an overall insufficient level of research competences within the scope of the medical doctorate, also when compared to the life sciences $(6,13)$.

However, even in the life sciences, graduates may not only pursue a doctorate out of pure research interest and/or in the pursuit of an (academic) research career. It is often presumed that the lack of job opportunities in and outside of academic research, push life scientists to pursue doctorates and even postdocs (19-21).

The reasons why students/graduates begin a doctorate, as well as general work and career attitudes, consequently affect career paths. For instance, links between intrinsic research and career motives (such as a pronounced intrinsic research interest) and the intention to pursue/pursuit of an academic research career have been empirically demonstrated (11, 22-24). Empirical findings on motives for obtaining a doctorate indicate that intrinsic dominate over extrinsic motives (25). However, there are also differences per subject group. In the natural sciences, for example, the motive of customariness applies more often than in other subjects $(26,27)$. There are also indications that employability is of greater importance in the life sciences. The study by Enders and Bornmann (26), based on data from 1999, showed that in biology the doctorate is more often perceived as a prerequisite for the desired career (cf. ibid: 52). These results were confirmed in a study by Schmidt (28) for the subject group "chemistry, biology and earth sciences". In an additional study by Spies \& Schute (29), it was found that labor market motives were more pronounced in biology than in mathematics. Due to the age of the analyzed data and partly due to a lack of clear-cut subject categories, there is no current subject-specific analysis of the motives for obtaining a doctorate.

Considering the field of medicine, a lower level of intrinsic research interest was shown compared to the life sciences (22). In a further study conducted at five faculties in the federal state of Baden-Württemberg, the majority of respondents stated that they had completed a doctorate out of customariness (30). However, detailed analyzes of motives for obtaining a doctorate in medicine have so far also been lacking.

With regard to the perceived meaningfulness of a doctorate - how sensible, i.e., 
meaningful, is/was the doctorate and for what reasons - there are only a few institution-specific

117 studies, which question medical doctoral graduates superficially. In these studies, the majority 118 of graduates agree with the general meaningfulness of their doctorate (31-33). However, it remains unclear for what reasons a doctorate is classified as meaningful or less meaningful (13). The qualitative doctoral thesis of Redies (34) deals with the perceived meaningfulness of the doctorate in medicine and comes to the conclusion that this does not always match the institutionally intended purpose of a doctorate, to certify the ability to conduct research independently.

Against the above background, we explore the question of why students and doctoral graduates in medicine and the life sciences actually choose to pursue their doctorate. This goal is associated with the question of what doctoral graduates, with subsequent different career paths, subjectively gain from their doctorate. Is the completion of the doctorate perceived as meaningful and why? If not, for what reason? Further, how do the initial motives match with the perceived meaningfulness?

We used two quantitative data sets to tackle this question. Data from the E-Prom study were used to analyze the motives for obtaining a doctorate in the life sciences alongside medical students and to compare the two subject groups. As the MediBAS study contained items specific to the field of medicine, it served for an in-depth analysis of the motives of medical graduates. Due to the content overlap of the items in both studies, the analysis of two samples also increases the validity of the results.

Based on the qualitative data, we analyze the motives for obtaining a doctorate in more detail and bring them together with respondents' perceived meaningfulness of the doctorate. The comparison between life sciences and medicine, as well as comparisons between genders,

\section{Methods}

To tackle our research questions, we used data from the E-Prom study, which was collected at the LMU Hospital Munich in cooperation with the Ludwig-Maximilians University of Munich, the Technical University of Munich and the University of Cologne (35) and has been approved by the ethics committee (Proposal 368-14). All study participants signed an informed declaration of consent, which informed them about the use of their data. In addition, we used data from the Medical Graduate Study (MediBAS). The Data of the MediBAS study were collected by the Bavarian State Institute for Higher Education Research and Planning 
149 (IHF) in cooperation with the Bavarian Competence Network for Medical Education Bavaria $150 \quad(\mathrm{KMB})(36)$.

\subsection{Quantitative Samples}

The MediBAS study was carried out from October 2018 to January 2019. Medical graduates (from human, veterinary medicine, and dentistry) from all Bavarian universities participated. Overall, 613 people took part in the survey. For our analyzes, the data regarding human medicine are relevant (cf. ibid.). In addition, people over the age of 45 were excluded from our analyzes because they are no longer considered as early career researchers (2). This leaves a sample of $\mathrm{N}=535$.

In addition, the three initial surveys of the doctoral study "E-Prom" with doctoral graduates in medicine and life sciences were used (35). Participants were recruited from 13 German universities and received their doctorate from a biological or medical faculty. The surveys were carried out in spring 2014, 2015 and 2016, respectively, with doctoral graduates who had completed their doctorate at a maximum of one year prior to the study. The data set comprises a total of $\mathrm{N}=1,825$ respondents. Doctoral students from the social sciences, humanities, veterinary medicine and dentistry who had earned a doctorate at medical/biological faculties, as well as persons over 45 years of age, were excluded for the purpose of the research questions, so that a data set of $\mathrm{N}=1,432$ was available.

\subsubsection{Operationalization}

E-Prom study: To analyze the motives for obtaining a doctorate, the participants answered why they had chosen to pursue a doctorate. Based on Berning and Falk (27) fifteen 5-point Likert scaled items $(1=$ completely disagree; $5=$ completely agree $)$ were collected (Table A2, Appendix, 37, 38). The data set with the variables used in the following analyzes was made available on the Figshare data repository (39).

MediBAS study: In the run-up to the MediBAS study, the items of the E-Prom study were used as a basis for creating a revised, medicine-specific instrument. Twelve 5-point Likert scaled items $(1=$ completely disagree; $5=$ completely agree $)$ were developed, including items such as "I wanted to do a doctorate in order to be perceived as a competent physician by patients" (36). The data are available from the IHF on request. 
For in depth analyzes of our research questions, we used qualitative interview data from the E-Prom project. The data and instruments of the study were archived with the consent of the participants and are available to other researchers for secondary analysis (40). As part of the study, ten doctoral graduates plus four doctoral candidates in human medicine were interviewed by telephone in $2014 / 2015$ using a structured interview guideline $(13,22,40)$. The respondents were recruited from the quantitative survey of the E-Prom project (cf. ibid.). The respondents were selected on the basis of their response behavior to the quantitative survey, thus ensuring that a balanced measure of more and less research interested people was surveyed in both subject groups (22). The qualitative interview study dealt with a wide range of questions in the domains of undergraduate and graduate studies, labor market entry and experiences.

193 Hence, our study represents distinct findings and no duplication of previous publications (13, $22,34)$. We excluded one social scientist with a doctorate in medicine and a female physician, who did not wish to answer the question of meaningfulness, from our analysis. This results in $\mathrm{N}=28$ respondents for the present study. The participants' characteristics are described in Table A1 (see Appendix).

\subsubsection{Data Analysis}

Based on the clearly defined research questions, which were followed up in the interviews, a content analysis according to Mayring was suitable for analyzing the interview material (41). We used the coding scheme developed as part of the E-Prom project as the basis of our analysis. The coding scheme was largely developed in a deductive manner, based on the interview questions and anticipated answer options, and was supplemented inductively with subcategories by assessing the answers of the respondents $(34,40)$. In the current study, we recoded the relevant text passages and revised the associated category system to achieve a better focus and fit on our research questions (see Table A2, Appendix). First and second author, independently of one another, double coded twenty percent of the interview material (three interviews from life sciences and three from medicine) paragraph by paragraph. For calculating the intercoder reliability (assessed by Cohen's Kappa (42)), the presence of the code was regarded as a match, since the overall classification/categorization of the person interviewed was relevant for answering our research question, whereas the exact location of the code was irrelevant. Cohen's Kappa (42) was determined to be 0.93 , which can be considered an almost perfect match (43). 


\subsection{Quantitative Results}

MediBAS Data: Table 1 shows the motives for obtaining a doctorate of the interviewed medical graduates, agreement in descending order.

221 Tab. 1: Motives for Obtaining a Doctorate, Agreement in Descending Order, MediBAS Data

\begin{tabular}{lccc} 
Motives for obtaining a doctorate & N & M & SD \\
\hline Customariness & 534 & 4.23 & 0.94 \\
Reputation in the eyes of patients & 534 & 3.73 & 1.19 \\
Disadvantages in the labor market & 532 & 3.41 & 1.28 \\
Gain subject-related knowledge & 534 & 3.27 & 1.33 \\
Keep the option of a research career open & 535 & 3.22 & 1.51 \\
Societal reputation & 535 & 3.19 & 1.31 \\
Intensive engagement with the topic of the doctorate & 535 & 3.00 & 1.38 \\
To better practice evidence-based medicine & 534 & 2.96 & 1.32 \\
Reputation in the eyes of colleagues & 534 & 2.87 & 1.36 \\
To research during the doctorate & 532 & 2.75 & 1.47 \\
To work in research after the doctorate & 534 & 2.44 & 1.41 \\
Higher income & 534 & 1.99 & 1.18 \\
\hline
\end{tabular}

Legend: Scale from $1=$ completely disagree, to $5=$ completely agree, mean values $(\mathrm{M})$ and standard deviations (SD) rounded to the second decimal place.

The customariness of the doctorate is the motive that clearly receives the greatest agreement. Furthermore, the expected reputation in the eyes of patients and the societal reputation in general are important motives. In comparison, reputation in the eyes of colleagues is less important. Feared disadvantages on the labor market and at least keeping the option of a research career open are also important factors in deciding to pursue a doctorate. Professional development, intensive engagement with the doctoral thesis topic and the subsequent practice of evidence-based medicine are in the middle of the range of motives for obtaining a doctorate. to generally work in research after the doctorate, receive medium approval ratings and rank third and second from last in the overall ranking.

When considering the distribution of approval to the individual categories, the respondents seem to part into a group of high, and into a group of very low or no interest in research (see Fig. 1): Only about 15 percent of respondents are in the middle approval category. Approximately 50 percent of those surveyed, stated that they did not want to do research during their doctorate, i.e., this was not a motive to start the doctorate (categories "completely 
the doctorate was not a motive (Fig.1, Item 3) and about 35 percent were not interested in

240 keeping their option of a research career open by obtaining a doctorate (Fig.1, Item 2). It is also interesting that the option of a research career receives higher approval than the motive to conduct research during and work in research after the doctorate.

\section{Fig.1: Research Interest When Chosing the Doctorate}

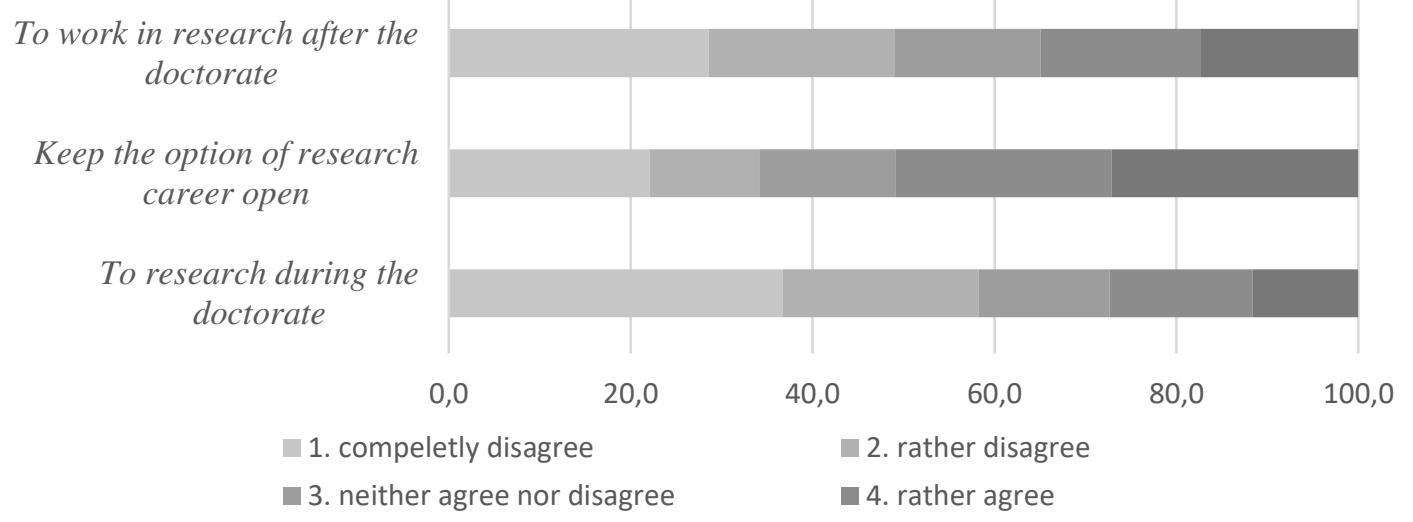

Table 2 shows the gender comparison. Differences in motives are visible in the areas of research and career. Female medical graduates attribute less importance to the aspects of "societal reputation", "reputation in the eyes of colleagues", and income when choosing to pursue a doctorate. Avoiding possible disadvantages on the labor market that may result from not having a doctoral degree is equally important to male and female medical graduates.

253 However, keeping the option of a research career open, as well as being able to do research

254 during their doctorate and to work in research after completing their doctorate, are motives also 255 rated significantly lower by female medical graduates. In addition, female graduates rate the motive to better practice evidence-based medicine by obtaining a doctorate significantly lower in comparison to male graduates.

Tab. 2: Motives for Obtaining a Doctorate by Gender, MediBAS Data

\begin{tabular}{lccc|cccc} 
& \multicolumn{3}{c}{ Male } & \multicolumn{5}{c}{ Female } \\
& $\mathrm{N}$ & $\mathrm{M}$ & $\mathrm{SD}$ & $\mathrm{N}$ & $\mathrm{M}$ & $\mathrm{SD}$ & $\mathrm{p}$ \\
\hline Customariness & 178 & 4.23 & 0.92 & 342 & 4.22 & 0.95 & 0.979 \\
Disadvantages in the labor market & 177 & 3.49 & 1.25 & 342 & 3.35 & 1.30 & 0.257 \\
To work in research after the doctorate & 177 & 2.65 & 1.45 & 344 & 2.32 & 1.38 & 0.013 \\
To research during the doctorate & 177 & 2.97 & 1.50 & 342 & 2.61 & 1.44 & 0.008
\end{tabular}




\begin{tabular}{llll|llll} 
Gain subject-related knowledge & 177 & 3.33 & 1.37 & 344 & 3.19 & 1.30 & 0.259 \\
Intensive engagement with the doctoral topic & 178 & 3.12 & 1.43 & 344 & 2.90 & 1.35 & 0.094 \\
Keep option of a research career open & 178 & 3.45 & 1.48 & 344 & 3.07 & 1.50 & 0.006 \\
To practice evidence-based medicine & 177 & 3.07 & 1.37 & 344 & 2.83 & 1.28 & 0.044 \\
Higher income & 178 & 2.34 & 1.33 & 343 & 1.81 & 1.04 & 0.000 \\
Societal reputation & 178 & 3.43 & 1.25 & 344 & 3.07 & 1.32 & 0.003 \\
Reputation in the eyes of patients & 178 & 3.75 & 1.23 & 343 & 3.73 & 1.18 & 0.788 \\
Reputation in the eyes of colleagues & 178 & 3.08 & 1.34 & 343 & 2.74 & 1.35 & 0.006 \\
\hline
\end{tabular}

Legend: scale from $1=$ completely disagree, to $5=$ completely agree, results are based on two-sided ttests, mean values $(\mathrm{M})$ and standard deviations $(\mathrm{SD})$ rounded to the second, $\mathrm{p}$-values rounded to the third decimal place. the E-Prom study by medicine and life sciences (see Table 3 and Figure 2) and by gender (see 263 Table 4).

Tab. 3: Motives for Obtaining a Doctorate, Life Sciences and Medicine, E-Prom Data

\begin{tabular}{|c|c|c|c|c|c|c|c|}
\hline & \multicolumn{3}{|c|}{ Life Sciences } & \multicolumn{3}{|c|}{ Medicine } & \multirow{3}{*}{$\begin{array}{c}\mathrm{p} \\
0.000\end{array}$} \\
\hline & $\mathrm{N}$ & $\mathrm{M}$ & SD & $\mathrm{N}$ & M & SD & \\
\hline Customariness & 693 & 3.93 & 1.25 & 739 & 4.44 & 0.82 & \\
\hline Improve career opportunities & 696 & 4.36 & 0.98 & 730 & 4.14 & 1.06 & 0.000 \\
\hline Gain subject-related knowledge & 690 & 4.19 & 0.95 & 730 & 3.62 & 1.17 & 0.000 \\
\hline $\begin{array}{l}\text { Intensive engagement with the doctoral } \\
\text { topic }\end{array}$ & 686 & 3.84 & 1.10 & 732 & 3.41 & 1.26 & 0.000 \\
\hline To research during the doctorate & 692 & 4.11 & 1.10 & 727 & 2.95 & 1.41 & 0.000 \\
\hline Was encouraged by people & 684 & 2.6 & 1.35 & 724 & 2.79 & 1.42 & 0.009 \\
\hline To work in research after the doctorate & 694 & 3.92 & 1.14 & 731 & 2.74 & 1.40 & 0.000 \\
\hline Higher income & 691 & 3.5 & 1.33 & 725 & 2.18 & 1.27 & 0.000 \\
\hline Lifestyle of a researcher & 689 & 2.69 & 1.35 & 724 & 1.93 & 1.16 & 0.000 \\
\hline It turned out that way & 683 & 1.96 & 1.21 & 721 & 1.68 & 1.08 & 0.000 \\
\hline Work in industrial research & 681 & 2.99 & 1.26 & 720 & 1.68 & 0.96 & 0.000 \\
\hline Not wanting to commit to a profession & 681 & 2.59 & 1.37 & 727 & 1.67 & 1.12 & 0.000 \\
\hline Flexibility of work and free time & 683 & 2.06 & 1.17 & 722 & 1.33 & 0.75 & 0.000 \\
\hline No alternative & 690 & 2.38 & 1.42 & 723 & 1.24 & 0.69 & 0,000 \\
\hline Work-life balance & 672 & 1.49 & 0.86 & 718 & 1.19 & 0.58 & 0.000 \\
\hline
\end{tabular}

Legend: scale from $1=$ completely disagree, to $5=$ completely agree, results based on two-sided ttests. Mean values $(\mathrm{M})$ and standard deviations $(\mathrm{SD})$ rounded to the second, $\mathrm{p}$-values to the third decimal place. customariness of a doctorate as the most important motive for obtaining a doctorate. Items that represent interest in research attract lower approval ratings in the middle area. Professional

270 development and intensive engagement with the topic of the doctorate receive higher approval 271 ratings. Medical doctoral graduates are also hoping for better career opportunities through 
272 having the title of "Dr". The "professional conditions" during the doctorate are of less

273 importance, which is not surprising, since they are mostly conducted during undergraduate 274 medical studies.

275 In the life sciences, customariness is also a strongly pronounced motive but significantly 276 less so than in medicine. In addition to customariness, the most important motives lie in the 277 areas of research interest and development of research competences, as well as in improving 278 career opportunities. All of these motives receive significantly higher approval than in 279 medicine. In particular, the items regarding research during and working in research after the 280 doctorate (also in the private sector), receive significantly higher approval ratings in the life 281 sciences. The motives "professional framework conditions during the doctorate" and "lack of 282 alternatives to the doctorate" receive generally little approval but significantly more in the life 283 sciences than in medicine. In both subject areas, it is rare for a doctorate to "just happen" with 284 the respondents simply not having thought about it much. Interestingly, doctoral graduates in 285 the life sciences agree somewhat more strongly here. Doctoral graduates in medicine are more 286 often encouraged to do a doctorate by a third person.

287 In a further analysis step, we examine the distribution of the approval ratings more 288 closely for the items regarding research orientation. The graphic representation of the 289 categories' characteristics in Figure 2 clearly shows the difference in research interest between 290 medicine and life sciences. In the life sciences, well over half of those questioned agree with 291 the statements that they decided to pursue a doctorate (also) in order to be able to do research 292 during the doctorate to work in research after the doctorate. The approval ratings here increase 293 steadily from the lowest to the highest level of agreement (see Fig. 2). In medicine on the 294 contrary, the approval ratings in the first and last two categories are almost equally distributed 295 and even tend to fall slightly. As with the MediBAS data, one can see a more or less divided 296 sample of those interested and those (completely) disinterested in research. 


\section{Fig. 2: Research Interest When Choosing to Obtain a Doctorate, Medicine (M) and Life Sciences (LS)}

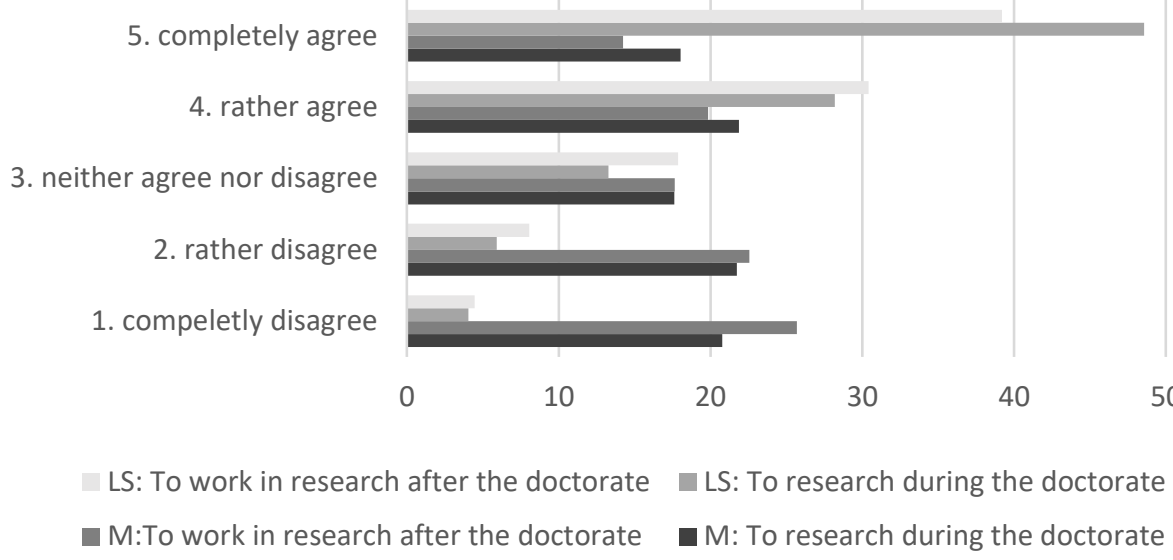

In the next step, we compare doctoral graduates by gender, while still differentiating by subject group (Table 4). We see significant gender differences in medicine, with female doctoral graduates showing slightly higher approval ratings for customariness as a motive and male doctoral graduates showing higher approval ratings regarding the motives to work in research after the doctorate generally and in the private sector.

Female in contrast to male life scientists, have significantly lower approval with regard to the motives wishing to work in the private research sector, lead the lifestyle of a researcher or have a higher income through a doctorate. Customariness as a motive is somewhat more pronounced among female doctoral graduates in the life sciences, as well as the statement that it just turned out that way. Interestingly, work-life balance as part of the doctorate is more important for men, however overall this motive seems to be not important.

Tab. 4: Motives for Obtaining a Doctorate in Life Sciences and Medicine, Compared by Gender

\begin{tabular}{|c|c|c|c|c|c|c|c|c|c|c|c|c|c|c|}
\hline & \multicolumn{7}{|c|}{ Life sciences } & \multicolumn{7}{|c|}{ Medicine } \\
\hline & \multicolumn{3}{|c|}{ Female } & \multicolumn{3}{|c|}{ Male } & \multirow[b]{2}{*}{$n$} & \multicolumn{3}{|c|}{ Female } & \multicolumn{3}{|c|}{ Male } & \multirow[b]{2}{*}{$\mathrm{p}$} \\
\hline & $\mathrm{N}$ & M & SD & $\mathrm{N}$ & M & SD & & $\mathrm{N}$ & M & SD & $\mathrm{N}$ & M & SD & \\
\hline Custo & 421 & 4.00 & 1.20 & 272 & 3.81 & 1.33 & 0.046 & 470 & 4.49 & 0.78 & 269 & 4.35 & 0.89 & 0.024 \\
\hline $\begin{array}{l}\text { To work in industrial } \\
\text { research }\end{array}$ & 410 & 2.90 & 1.23 & 271 & 3.13 & 1.28 & 0.018 & 459 & 1.61 & 0.87 & 261 & 1.82 & 1.09 & 0.005 \\
\hline $\begin{array}{l}\text { To work in research } \\
\text { after doctorate } \\
\text { Gain subject-related }\end{array}$ & 420 & 3.93 & 1.17 & 274 & 3.91 & 1.09 & 0.811 & 461 & 2.62 & 1.39 & 270 & 2.95 & 1.40 & 0.002 \\
\hline $\begin{array}{l}\text { knowledge } \\
\text { To research during th }\end{array}$ & 418 & 4.15 & 0.96 & 272 & 4.25 & 0.95 & 0.187 & 462 & 3.58 & 1.17 & 268 & 3.68 & 1.18 & 0.273 \\
\hline $\begin{array}{l}\text { docto } \\
\text { Inten }\end{array}$ & 421 & 4.11 & 1.09 & 271 & 4.11 & 1.12 & 0.969 & 461 & 2.87 & 1.39 & 266 & 3.08 & 1.43 & 0.047 \\
\hline with $t$ & 414 & 3.82 & 1.09 & 272 & 3.87 & 1.12 & 0.579 & 464 & 3.36 & 1.27 & 268 & 3.50 & 1.25 & 0.173 \\
\hline Lifestyle of a researcher & 415 & 2.58 & 1.31 & 274 & 2.85 & 1.40 & 0.008 & 459 & 1.89 & 1.12 & 265 & 2.01 & 1.22 & 0.193 \\
\hline
\end{tabular}


Improve career

opportunities

Higher income

Not wanting to commit

to a profession

No alternative

Flexibility of work and

free time

Work-life balance

It turned out that way

\begin{tabular}{lll|llll|lll||llll}
423 & 4.36 & 0.98 & 273 & 4.37 & 0.98 & 0.926 & 460 & 4.19 & 1.04 & 270 & 4.06 & 1.08 & 0.119 \\
418 & 3.41 & 1.34 & 273 & 3.63 & 1.30 & 0.027 & 458 & 2.06 & 1.19 & 267 & 2.38 & 1.37 & 0.868 \\
& & & & & & & & & & & & & \\
411 & 2.64 & 1.39 & 270 & 2.51 & 1.36 & 0,240 & 460 & 1.70 & 1.15 & 267 & 1.62 & 1.06 & 0.350 \\
419 & 2.48 & 1.43 & 271 & 2.23 & 1.40 & 0.019 & 458 & 1.24 & 0.72 & 265 & 1.23 & 0.64 & 0.764 \\
& & & & & & & & & & & & & \\
413 & 2.00 & 1.11 & 270 & 2.17 & 1.24 & 0.064 & 457 & 1.32 & 0.73 & 265 & 1.35 & 0.77 & 0.588 \\
410 & 1.43 & 0.81 & 262 & 1.58 & 0.94 & 0.035 & 456 & 1.15 & 0.48 & 262 & 1.28 & 0.72 & 0.518 \\
414 & 2.07 & 1.23 & 269 & 1.78 & 1.14 & 0.002 & 457 & 1.68 & 1.08 & 264 & 1.68 & 1.10 & 0.976 \\
416 & 2.63 & 1.35 & 268 & 2.53 & 1.37 & 0.341 & 456 & 2.82 & 1.39 & 268 & 2.74 & 1.48 & 0.449
\end{tabular}

Encouraged by people

Legend: scale from $1=$ completely disagree, to $5=$ completely agree, results based on two-sided t-tests. Mean values $(\mathrm{M})$ and standard deviations (SD) rounded to the second, $\mathrm{p}$-values to the third decimal place.

\subsubsection{Comparison of Research Interested and Disinterested Graduates}

Next, we analyze whether research interested graduates in medicine and life sciences also differ significantly in terms of their other motives from their colleagues who are rather disinterested in research. Are these, as already shown in other subject groups, "intrinsically motivated and willing to do without" (44)? For this purpose, we formed two groups based on the motives "do research during the doctorate" and "work in research after the doctorate", respectively with the MediBAS and E-Prom data. People with high approval ratings on both items ("rather agree" and "completely agree") were categorized as research interested whereas

321 people with (very) low approval ratings in both variables ("rather disagree" and "completely

322 disagree") were categorized as people disinterested in research. Undecided respondents in the 323 middle category ("partially agree") were left out for reasons of ambiguity. In addition, the

324 motive to "keep the option of a research career open" was disregarded here, since respondents 325 may have focused more on the career than the research aspect. We compared the attained 326 groups, using two-sided t-tests, regarding their career and prestige orientation but also with 327 respect to the motive of customariness and compared (see Table 5 and Table 6).

329 Tab. 5: Comparison of Research Interested and Disinterested, Medicine

\begin{tabular}{|c|c|c|c|c|c|c|c|c|c|c|c|c|c|c|}
\hline & \multicolumn{7}{|c|}{ MediBAS Data } & \multicolumn{7}{|c|}{ E-Prom Data } \\
\hline & \multicolumn{3}{|c|}{ Disinterested } & \multicolumn{3}{|c|}{ Interested } & & \multicolumn{3}{|c|}{ Disinterested } & \multicolumn{3}{|c|}{ Interested } & \multirow[b]{2}{*}{$\mathrm{p}$} \\
\hline & $\mathrm{N}$ & $\mathrm{M}$ & $\mathrm{SD}$ & $\mathrm{N}$ & M & $\mathrm{SD}$ & & $\mathrm{N}$ & $\mathrm{M}$ & SD & $\mathrm{N}$ & M & $\mathrm{SD}$ & \\
\hline Customariness & 227 & 4.33 & 0.89 & 116 & 4.10 & 1.03 & 0.035 & 235 & 4.62 & 0.61 & 187 & 4.16 & 1.08 & 0.000 \\
\hline Higher income & 228 & 1.86 & 1.22 & 116 & 2.28 & 1.23 & 0.002 & 232 & 2.10 & 1.28 & 187 & 2.41 & 1.33 & 0.016 \\
\hline $\begin{array}{l}\text { Improve career } \\
\text { opportunities }\end{array}$ & & & & & & & & 233 & 3.93 & 1.16 & 186 & 4.31 & 0.97 & 0.428 \\
\hline $\begin{array}{l}\text { Reputation in } \\
\text { society }\end{array}$ & 229 & 3.27 & 1.29 & 116 & 3.15 & 1.42 & 0.413 & & & & & & & \\
\hline
\end{tabular}


Reputation in the eyes of patients

Reputation in the

eyes of colleagues

\begin{tabular}{|lll|lll|l|}
229 & 3.90 & 1.06 & 116 & 3.52 & 1.39 & 0.043 \\
229 & 2.81 & 1.34 & 116 & 2.98 & 1.47 & 0.281 \\
\hline
\end{tabular}

Legend: scale from $1=$ completely disagree, to $5=$ completely agree, results based on two-sided t-tests. Mean values

(M) and standard deviations (SD) rounded to the second, p-values to the third decimal place.

When comparing medical doctoral graduates who are interested in science and those not

332 interested (see Table 5), those who are interested in science tend to have a stronger career

333 orientation: The group of those interested in science shows significantly higher approval ratings

334 regarding the motives "higher income" and "reputation in the eyes of patients". This group

335 agrees significantly less with the customariness motive, although approval remains very high.

336 In the life sciences, the disinterested group who do not agree at all or only somewhat

337 with the motive of doing research during the doctorate or afterwards is very low (see Table 6).

338 In medicine, more than half of the respondents in this data set fall into this group (see Table 5).

339 In the life sciences, there are also no significant differences between the two groups with regard

340 to career motivations. In contrast to medicine, research interested respondents in the life

341 sciences agree more strongly to the motive of customariness than those disinterested.

343 Tab. 6: Comparison of Research Interested and Disinterested, Life Sciences

\begin{tabular}{lccc|ccc|c}
\hline & \multicolumn{3}{c|}{ Disinterested } & \multicolumn{3}{c|}{ Interested } & \\
& $\mathrm{N}$ & $\mathrm{M}$ & $\mathrm{SD}$ & $\mathrm{N}$ & $\mathrm{M}$ & $\mathrm{SD}$ & $\mathrm{p}$ \\
\hline Customariness & 25 & 3.44 & 1.36 & 397 & 3.98 & 1.22 & 0.035 \\
Higher income & 25 & 3.56 & 1.23 & 396 & 3.31 & 1.31 & 0.361 \\
Improve career opportunities & 25 & 4.28 & 1.14 & 400 & 4.30 & 1.00 & 0.428 \\
\hline
\end{tabular}

Legend: Scale from $1=$ completely disagree, to $5=$ completely agree, results based on two-sided t-tests. Mean

values $(\mathrm{M})$ and standard deviations $(\mathrm{SD})$ rounded to the second, $\mathrm{p}$-values to the third decimal place.

\subsection{Qualitative results}

The results of the qualitative study are presented below. Because there was a balanced pre-selection of people more and less research interested, relative and absolute frequencies (as

348 in any qualitative study) should not be understood as representative (see also Chapter 2.2.1).

349 Rather, they serve the in-depth analysis of the content of motives for obtaining a doctorate and

350 the perceived meaningfulness of the doctorate. The quotations are freely translated from

351 German to English by the authors.

\subsubsection{Motives for Obtaining a Doctorate and Meaningfulness, Life Sciences}

Motives for obtaining a doctorate: When analyzing the qualitative interviews, the meaning of the motive "customariness" becomes clear: in the life sciences, the high proportion 
of those obtaining a doctorate, is related to feared career disadvantages without a doctorate.

“OK, I honestly didn't think about it that much at the time. It was clear to me that I would do a doctorate afterwards. On the one hand, because I still could envisage neither an academic career nor something like an industrial research career. On the other hand because I wanted to do it too and because, maybe due to a lack of information, even though I'm still a bit, that in this sector it's beneficial for most jobs - if not even a requirement - to have a doctorate. So therefore I have never seriously considered not doing a doctorate." (ID 7, life sciences, section 36)

Feared professional disadvantages are great motivation for pursuing a doctorate and are cited as a reason by nine of the fourteen respondents (see also Appendix, Table A1). In this context, it is also mentioned that lecturers described a doctorate as an obligatory professional qualification to their undergraduate students. Not only the goal to avoid negative professional consequences, but occupational motives in general are of great importance in the life sciences. A further six respondents mention (the possibility of) a research career as a motive for obtaining a doctorate. Two other respondents named positively formulated professional goals outside of academic research. In addition to a research career, the development of research skills plays an important role which on the one hand can be purely interest-driven but can also be important for a later career, for example also in industrial research.

Meaningfulness: Twelve out of fourteen respondents in the life sciences were certain that their doctorate was sensible. The justification of the doctorate's meaningfulness is related to the current life situation but also to the initial motives for obtaining a doctorate. Those who kept working in academic research see the doctorate as the path leading to the postdoc position, especially if this was a goal from the outset. Postdocs at universities also mention the acquisition of research skills but with only three mentions, this is much less common. The acquisition of research competences is likely not addressed separately as a natural prerequisite for an academic research career.

Employees in other professional branches justify their doctorate's meaningfulness in particular with the acquisition of general skills and personal development (working independently, perseverance, problem solving, etc.), but also state that a doctorate was a prerequisite for their position. If the current professional position does not match the original goal, respondents justify their doctorate's meaningfulness with possible professional prospects and developments in the future. However, also postdocs in academia emphasize the aspects of general skills and personal development. In addition to professional aspects, these two aspects are, overall, mentioned most frequently (see Table A1).

"Yes. I think so. As you have your own project during a doctorate, of course, you learn a lot 
through that, setting up a project, project management, dealing with other people, er and yes, in any case, of course, you continue to develop. Not just professionally but the soft skills around it." (ID 8, life sciences, section 161)

Overall, the reputation of having a doctoral title is of little importance here $(\mathrm{N}=2)$. Those interviewees who express uncertainty about their doctorate's meaningfulness do not differ in in their justifications of meaningfulness. Their uncertainty results from the doubt about whether the doctorate really was a prerequisite for starting a career (ID 3) and due to negative experiences during the doctorate: compare the initial motives (albeit retrospectively) with the assessment of the meaningfulness, the categories coincide very well for the most part. However, there are some interesting deviations. Regarding professional and career aspects, these are equally strongly represented among the motives as well as the perceived meaningfulness in retrospect. It is interesting that research interest or the development of research competences is more common as a motive ( $\mathrm{N}$ $=6)$ but rarely mentioned as a justification of meaningfulness in retrospect $(\mathrm{N}=3)$. No clear pattern can be discerned in terms of the characteristics that lead to a mention or non-mention. It is likely that the low attention to this aspect as a justification of meaningfulness is due to the higher focus on the direct transfer of competences acquired during the doctorate into the current professional activity. What also stands out is that the area of or general skills and personal development is only recognized after the doctorate.

\subsubsection{Motives for Obtaining a Doctorate and Meaningfulness, Medicine}

Motives for obtaining a doctorate: About half of those surveyed in medicine cite research interest or development of research competences as the reason for considering the doctorate as meaningful $(\mathrm{N}=7)$. The primary goal is getting to know academic research in order to include or exclude this for one's own professional career.

"So [not] doing a doctoral thesis, with it being so common in medicine, but I wanted to get an insight into research. And to find out if this is something for me. And beyond that, whether you want to continue at university later on and maybe continue doing research. Or if you can 
categorically exclude research, then the career path in medicine veers more towards the peripheral institutions rather than university. (...)” (ID 7, Medicine, Sections 59-62)

The customariness of a doctorate and the anticipated reputation by bearing a doctoral title play a major role, with five mentions each. Customariness relates to reputation in that a physician without the title might possibly "scare off" patients. Two of the respondents mention customariness without further substantive reasons. This gives the impression of doctorates as more of a habitual choice, possibly based to a lesser extent on cost-benefit considerations (45).

"Yeah well, it's of course common practice in medical studies to actually start during this time. And, for the most part at least, to get it finished. And so of course almost everyone started studying, er, working on their doctorate in the fifth to seventh semesters, and of course I followed suit." (ID2, medicine, sections 45-47)

"Yes, so somehow I thought, that, that it's part and parcel of it and that somehow was an incentive to get the title. But not, because I'm better regarded among colleagues or something. Not that. So a, a kind of a starting point. Somehow, it was part of it. Cause, I also had friends at university, they all did it, that's why for me it's part and parcel of it." (ID 5, Medicine, Section 42)

Meaningfulness: Most participants justify their doctorate's meaningfulness with the acquisition of general skills and personal development $(\mathrm{N}=6)$. Four of the 13 respondents cited the development of research competences as a reason. Two respondents cited the pursuit of a research career, with only one of these respondents sincerely planning one. In addition, two participants justified the meaningfulness of their doctorate by being able to exclude a research career for them personally, as well as the reputation by bearing a doctoral title $(\mathrm{N}=2)$.

Comparison of initial motives for obtaining a doctorate and meaningfulness: Respondents, who cited the reputation of the title as only motive for obtaining a doctorate, also justified the meaningfulness only through being able to bear the title. These respondents were also unsure about evaluating the meaningfulness positively. Those who indicated research interest and development of research competences as motives also justified their doctorate's meaningfulness with the development of research competences, but especially the acquisition of general skills and personal development (34).

\section{Summary and Discussion}

The present study dealt with the motives for obtaining a doctorate and the perceived 
meaningfulness of the doctorate in medicine and life sciences. In particular, the question arose as to what extent common stereotypes of the "biologist with no job perspectives" and the "prestige-motivated" medical professional apply. We further examined to what extent research interested and disinterested in both subject groups differ with regard to their career and prestige orientation. In addition, we used a qualitative data to analyze the perceived meaningfulness of the doctorate and the relation between initial motives and (justifications of) meaningfulness.

For the life sciences, we found that the customariness of doctorates, which emerged quantitatively as an important motive, largely reflects the fear of experiencing disadvantages on the labor market without a doctorate. However, doctoral graduates also question the truth behind this presumption. Further motives in the life sciences are positively formulated career goals in and outside of academic research, and a desire to develop one's research competences during the doctorate further. The majority of doctoral graduates in the life sciences are (very) interested in research when choosing to do a doctorate and aim to not only do research during their doctorate, but to continue to work in research after graduation. The comparison between the larger group of research interested with the very small group of those rather disinterested revealed no significant differences in career orientation. It can thus be assumed that a pronounced research interest does not go hand in hand with less pronounced extrinsic motives, as demonstrated in other subject groups (44). Interestingly, research interested respondents agreed more strongly to the motive of customariness, possibly because a research career is only possible with a doctorate. In the life sciences, the meaningfulness of the doctorate is mainly associated with the chosen career path and (hoped for) professional advantages. In addition, great importance is attached to the acquisition of general skills and personal development.

In medicine, the customariness of doing a doctorate and, in this context, the societal reputation and reputation in the eyes of patients are important motives for obtaining a doctorate. With regard to research interest when choosing to pursue a doctorate, a clear division emerged between medicine and the life sciences. About half of the respondents from the two samples gave (very) low approval ratings for wanting to do research during or after the doctorate as motives. This gives the impression that a considerable proportion of medical doctoral graduates may have pursued the doctorate for habitual reasons and "following the mainstream".

On the other hand, the acquisition of subject-related skills in the context of the doctorate was of greater importance. It is possible that the doctorate is seen or used as a preparation for further medical education. This assumption should be followed up in further studies.

As part of the qualitative interviews, it was found that medical doctoral graduates, who merely wanted to acquire a doctoral degree to bear the title, were hesitant in describing their 
doctorate as meaningful, and reduced its meaningfulness to the ability to bear the title. Since (justifications of) meaningfulness were not quantified, this result cannot be transferred to the whole group of those who were categorized as disinterested in research. It is interesting, however, that this group was also rather less pronounced in terms of career and prestige orientation. Medical graduates who chose to do a doctorate because of their research interest gave higher approval ratings to the motives "higher income" as well as "reputation in the eyes of patients". This result could be explained by the fact that for a medical career at (university) hospitals, certain clinical and research duties are expected, so the research sector here attracts those less "intrinsically motivated and willing to do without" (44). This could also explain, medical doctoral graduates affirmed more strongly the motive of keeping the option of a research career open than the motive of working in research after obtaining the doctorate.

With the qualitative data, we can show that motives for obtaining a doctorate in both subject areas are closely linked to perceived meaningfulness in retrospect. In the life sciences, there was a strong connection with the current professional situation. Professional aspects play a much more important role in the life sciences compared to medicine, both as regards motives and justifications for meaningfulness. In medicine, the only important professional aspects are the reputation in the eyes of patients and in few instances continuing one's academic research career.

Overall, our analyzes indicate that the development of research competencies and having at least the option to pursue an academic research career after the doctorate play a significantly more important role in life sciences than in medicine. Even when only looking at medicine, conducting research during and after the doctorate rather lag behind as motives to obtain a doctorate in comparison to the other motives assessed. The on average lower competence level following the doctorate in medicine when compared to the life sciences (6), therefore probably can be traced back to differences in research interest and in undergraduate and graduate research education.

With regard to gender, we find differences in the life sciences but in particular in medicine. In both subjects, female in comparison to male graduates show significantly lower agreement to career motives. In addition, female medical graduates express significantly lower research interest and agree significantly less to the motive of better practicing evidence-based medicine. This raises the question of why female medical professionals in particular are less interested in research than their male counterparts are. In line with these results, a lower research-related self-efficacy among female doctoral graduates compared to male doctoral graduates in medicine (6) and a lower publication activity after completion of the doctorate was 
523 found (46). It is conceivable that there is a self-selection bias among the female population of

524 medical students, so that females who exhibit less pronounced career goals (clinical or research 525 related) chose medicine more often as a field of study than females with the reverse profile.

526 However, since the career orientation among females was less pronounced in both subject 527 groups, the reasons for this may be more firmly anchored in society and should be examined 528 separately and comprehensively in further studies.

\section{Declarations}

531 Ethics Approval and Consent to Participate: The ethics committee of the LMU Hospital

532 Munich (Proposal 368-14) approved of the E-Prom study, both quantitative and qualitative.

533 All study participants signed an informed consent. The informed consent signed by all study

534 participants included a consent of publication.

536 Availability of Data and Materials: The E-Prom survey dataset was deposited at the repository 537 figshare (doi: 10.6084/m9.figshare.11967741). Qualitative data can be requested from the data 538 repository QualiService (www.qualiservice.org). The MediBAS data can be requested from the 539 Bavarian Institute of Higher Education Research and Planning (www.ihf.bayern.de).

541 Conflicts of Interest: The authors declare no conflict of interest:

543 Funding: The E-Prom study was funded by the Federal Ministry of Education and Research 544 (BMBF) (FKZ 16FWN010-13).

546 Authors' Contributions: Concept: NE, DL; KR, Quantitative Data Analysis: NE; Qualitative 547 Coding Scheme: NE, KR; Qualitative Analysis: NE, JH; Overall data interpretation: NE, JH; 548 Critical revision of manuscript drafts and final manuscript: DL, KR, JH, SH.

550 Acknowledgments: We would like to thank our partners of the Bavarian State Institute for 551 Higher Education Research and Panning, specifically Maike Reimer, and partners of the E552 Prom study. In this context, we would also like to thank the participants of all three studies. 


\section{References}

1. Teichler U. Der Weg vor und nach der Promotion in Deutschland-per aspera ad astra? 2016. In: Lern-und Bildungsprozesse gestalten Junges Forum Medien und Hochschulentwicklung (JFMH13) [Internet]. [61-78]. Available from: http://nbn-resolving.de/urn:nbn:de:0111-pedocs16775.

2. Nachwuchs KBW. Bundesbericht Wissenschaftlicher Nachwuchs 2017. W. Bertelsmann Verlag; 2017. Report No.: 3763958509.

3. Nachwuchs KBW. Bundesbericht wissenschaftlicher Nachwuchs 2013: Statistische Daten und Forschungsbefunde zu Promovierenden und Promovierten in Deutschland. 2013. Report No.: 3763950826.

4. Kreckel R. Zur Lage des wissenschaftlichen Nachwuchses an Universitäten: Deutschland im Vergleich mit Frankreich, England, den USA und Österreich. Beiträge zur Hochschulforschung. 2016;38(1-2):12-40.

5. Schwencke S. Neue Serie: Richtig promovieren (1): Wozu eigentlich?-Großer Hut, und nichts darunter? Via medici. 2010;15(01):14-6.

6. Epstein N, Fischer MR. Academic career intentions in the life sciences: Can research selfefficacy beliefs explain low numbers of aspiring physician and female scientists? PloS one. 2017;12(9).

7. Hornbostel S. Einleitung 2012. In: Der Doktortitel zwischen Status und Qualifikation [Internet]. DEU; [192].

8. Destatis. Prüfungen an Hochschulen 2013. Statistisches Bundesamt 2014.

9. Gesellschaft Deutscher Chemiker. Statistik der Chemiestudiengänge 2018. Available from: https://www.gdch.de/fileadmin/downloads/Ausbildung_und_Karriere/Karriere/Statistik/Broschuere _web/2018_Statistik_web.pdf.

10. Flöther C. Promovierte auf dem außeruniversitären Arbeitsmarkt: mehr als ein „Plan B“. WSIMitteilungen. 2017;70(5):356-63.

11. Briedis K, Jaksztat S, Preßler N, Schürmann R, Schwarzer A, editors. Berufswunsch Wissenschaft. Laufbahnentscheidungen für oder gegen eine wissenschaftliche Karriere Forum Hochschule; 2014.

12. Epstein N, Pfeiffer M, Eberle J, von Kotzebue L, Martius T, Lachmann D, et al. Nachwuchsmangel in der medizinischen Forschung. Wie kann der ärztliche Forscher-nachwuchs besser gefördert werden? Beiträge zur Hochschulforsch. 2016;38:162-89.

13. Epstein N, Huber J, Gartmeier M, Berberat PO, Reimer M, Fischer MR. Investigation on the acquisition of scientific competences during medical studies and the medical doctoral thesis. GMS journal for medical education. 2018;35(2).

14. Roberts SF, Fischhoff MA, Sakowski SA, Feldman EL. Perspective: Transforming Science Into Medicine How Clinician-Scientists Can Build Bridges Across Research's "Valley of Death". Academic Medicine. 2012;87(3):266-70.

15. Ills of the System. Reform is long overdue for Germany's archaic medical-education system, which puts undue pressure on students and contaminates the scientific literature. Nature2015.

16. Diez C, Arkenau C, Meyer-Wentrup F. The German medical dissertation-Time to change? Academic Medicine. 2000;75(8):861-3.

17. Grevers L. Medizinstudenten in Deutschland lernen kaum, wie wissenschaftlich gearbeitet wird. Deshalb sollen sie nun mehr schreiben - oder das Promovieren lassen. Sueddeutsche. 2017

18. Gaethgens P. Ramschware Dr. med.? Die Zeit. 2015.

19. Plasa TN. Studienbedingungen und Berufseinstieg in der Biologie. Biologie in unserer Zeit. 2014;44(6):364-6.

20. Klöck G. Berufschancen für Bachelor und Master in der Biologie: Mehr als Praktikum oder Pharmaberater? Biologie in unserer Zeit. 2010;40(6):375-6. 
21. Jaksztat S, Schindler N, Briedis K. Wissenschaftliche Karrieren-Beschäfti gungsbedingungen, berufliche Orientierungen und Kompetenzen des wissenschaftlichen Nachwuchses. 2010.

22. Epstein N. Achievement related cognitions and the intention of doctoral graduates in medicine and life sciences to pursue an academic research career: LMU; 2016.

23. Lachmann D, Epstein N, Eberle J. FoSWE-Eine Kurzskala zur Erfassung forschungsbezogener Selbstwirksamkeitserwartung. Zeitschrift für Pädagogische Psychologie. 2018. 24. Roach M, Sauermann H. A taste for science? PhD scientists' academic orientation and selfselection into research careers in industry. Research policy. 2010;39(3):422-34.

25. Krempkow R. (Selbst) Selektionen zur Promotion. Ansätze zur Schätzung von Selektivität bei Zugang und Verlauf mit Hilfe von Absolventenbefragungen und Hochschulstatistiken. BülowSchramm, Margret (Hg): Hochschulzugang und Übergänge in der Hochschule: Selektionsprozesse und Ungleichheiten Frankfurt S. 2009:197-213.

26. Enders J, Bornmann L. Karriere mit Doktortitel?: Ausbildung, Berufsverlauf und Berufserfolg von Promovierten: Campus Verlag; 2001.

27. Berning E, Falk S. Das Promotionswesen im Umbruch. Beiträge zur Hochschulforschung. 2005;27(1):48-72.

28. Schmidt B. Alles anders? Unterschiede und Gemeinsamkeiten im Promotionsgeschehen verschiedener Fächergruppen. Die Hochschule: Journal für Wissenschaft und Bildung. 2009;18(2):126-52.

29. Spies K, Schute M. Warum promovieren Frauen seltener als Männer? Psychologische Prädiktoren der Promotionsabsicht bei Männern und Frauen. Zeitschrift für Sozialpsychologie. 1999. 30. Giesler M, Boeker M, Fabry G, Biller S. Importance and benefits of the doctoral thesis for medical graduates. GMS journal for medical education. 2016;33(1).

31. Pabst R, Park D-H, Paulmann V. Die Promotion in der Medizin ist besser als ihr Ruf. DMWDeutsche Medizinische Wochenschrift. 2012;137(45):2311-5.

32. Pabst R, Strate J, Rothkoetter H-J. Die medizinische Dissertation: Sinnvolle Ergaenzung oder Ablenkung vom Studium? DEUTSCHES ARZTEBLATT-KOLN. 1997;94:1886-9.

33. Weihrauch M, Strate J, Pabst R. Die medizinische Dissertation-kein Auslaufmodell. DMWDeutsche Medizinische Wochenschrift. 2003;128(49):2583-7.

34. Redies KM. Zur Sinnhaftigkeit der Promotion aus Sicht humanmedizinisch Promovierter: Ludwig-Maximilians-Universität München (LMU); 2019.

35. Fischer MR, Epstein N. Einfluss der Promotionsphase auf die Karriere von Nachwuchswissenschaftlerinnen und Nachwuchswissenschaftlern in den Lebenswissenschaften (EProm)-Teilprojekt am Institut für Didaktik und Ausbildungsforschung in der Medizin: ein Verbundprojekt des Förderschwerpunkts Wissenschaftlicher Nachwuchs-FoWiN: Institut für Didaktik und Ausbildungsforschung in der Medizin, Klinikum der Universität Mümchen; 2017. doi.org/10.2314/GBV:889790442

36. Reimer M. Methodenbericht der 1. MediBAS-Befragung Bayerisches Staatsinstitut für Hochschulforschung und Hochschulplanung (IHF) 2018.

37. Fischer MH, Stefan; Neuhaus, Birgit J.; Prenzel, Manfred; Berberat, Pascal: Einfluss der Promotionsphase auf die Karriereentwicklung von NachwuchswissenschaftlerInnen in der Medizin und den Lebenswissenschaften, Kohorte 1 (E-Prom). GESIS, 2017. doi.org/10.4232/1.12713

38. Fischer MH, Stefan; Neuhaus, Birgit J.; Prenzel, Manfred; Berberat, Pascal: Einfluss der Promotionsphase auf die Karriereentwicklung von NachwuchswissenschaftlerInnen in der Medizin und den Lebenswissenschaften, Kohorte 2 (E-Prom). GESIS, 2017. doi.org/10.4232/1.12714

39. Epstein N, Lachman D: Reasons to Pursue a PhD/Dr.med. 2020. doi: 10.6084/m9.figshare.11967741

40. Fischer MR, Epstein, N., Pfeiffer, M. Einfluss der Promotionsphase auf die Karriere von Nachwuchswissenschaftlerinnen und Nachwuchswissenschaftlern in den Lebenswissenschaften, Studie 2. 2017. (Data availabe from: https://www.qualiservice.org/de/daten-services/datennutzen/daten-nutzen-datenbestand.html) 
41. Mayring P. Qualitative Inhaltsanalyse. Handbuch qualitative Forschung in der Psychologie: Springer; 2010. p. 601-13.

42. Cohen J. Weighted kappa: nominal scale agreement provision for scaled disagreement or partial credit. Psychological bulletin. 1968;70(4):213.

43. Landis JR, Koch GG. An application of hierarchical kappa-type statistics in the assessment of majority agreement among multiple observers. Biometrics. 1977:363-74.

44. Abele AE, Krüsken J. Intrinsisch motiviert und verzichtbereit. Zeitschrift für Sozialpsychologie. 2003;34(4):205-18.

45. Esser H. Rationalität und Bindung: das Modell der Frame-Selektion und die Erklärung des normativen Handelns. 2005.

46. Pfeiffer M, Fischer MR, Bauer D. Publication activities of German junior researchers in academic medicine: which factors impact impact factors? BMC medical education. 2016;16(1):190. 


\section{Appendix}

Tab. A1: Description of Participants' Characteristics

\begin{tabular}{|c|c|c|c|c|c|c|c|}
\hline ID & Age & Gender & Occupation/ Position & $\begin{array}{l}\text { Research } \\
\text { Involvement }\end{array}$ & Motives to Obtain a Doctorate & $\begin{array}{l}\text { Meaningful } \\
\text { /Sensible }\end{array}$ & Justification of Meaningfulness \\
\hline \multicolumn{8}{|c|}{ Medicine } \\
\hline 1 & 29 & $\mathrm{~m}$ & $\begin{array}{l}\text { Assistant physician, university } \\
\text { hospital }\end{array}$ & $100 \%$ & $\begin{array}{l}\text { 1) research interest and research } \\
\text { competence development } \\
\text { 2) (option of) research career }\end{array}$ & yes & $\begin{array}{l}\text { 1) research career/engaging in research activities } \\
\text { 2) general skills and personality development }\end{array}$ \\
\hline 2 & 33 & $\mathrm{~m}$ & $\begin{array}{l}\text { Specialist general medicine, } \\
\text { medical practice }\end{array}$ & - & 1) customariness & ambivalent & 1) general skills and personality development \\
\hline 3 & 32 & $\mathrm{~m}$ & $\begin{array}{l}\text { Research manager, extramural } \\
\text { research institution }\end{array}$ & - & $\begin{array}{l}\text { 1) research interest and research } \\
\text { competence development } \\
\text { 2) (option of) research career }\end{array}$ & yes & 1) acquisition of research competences \\
\hline 5 & 32 & $\mathrm{w}$ & $\begin{array}{l}\text { Assistant physician in } \\
\text { dermatology, hospital }\end{array}$ & - & 1) customariness & yes & $\begin{array}{l}\text { 1) career orientation/exclusion of research career } \\
\text { 2) other: pride }\end{array}$ \\
\hline 6 & 28 & $\mathrm{w}$ & $\begin{array}{l}\text { Assistant physician orthopedic, } \\
\text { hospital }\end{array}$ & - & $\begin{array}{l}\text { 1) customariness } \\
\text { 2) prestige }\end{array}$ & ambivalent & $\begin{array}{l}\text { 1) career orientation/ exclusion of research } \\
\text { career }\end{array}$ \\
\hline 7 & 28 & $\mathrm{w}$ & $\begin{array}{l}\text { Assistant physician in } \\
\text { neurology, university hospital }\end{array}$ & $100 \%$ & $\begin{array}{l}\text { 1) research interest and research } \\
\text { competence development } \\
\text { 2) (option of) research career }\end{array}$ & yes & $\begin{array}{l}\text { 1) acquisition of research competences } \\
\text { 2) research career/engaging in research activities }\end{array}$ \\
\hline 9 & 27 & $\mathrm{w}$ & $\begin{array}{l}\text { Assistant physician psychology } \\
\text { and psychotherapy, hospital }\end{array}$ & - & 1) prestige & yes & 1) obtaining title/prestige \\
\hline 10 & 31 & $\mathrm{~m}$ & $\begin{array}{l}\text { Assistant physician } \\
\text { neuroradiology, university } \\
\text { hospital }\end{array}$ & $\begin{array}{l}\text { Patient care and } \\
\text { research }\end{array}$ & $\begin{array}{l}\text { 1) research interest and research } \\
\text { competence development } \\
\text { 2) prestige (here with } \mathrm{PhD} \text { ) }\end{array}$ & yes & 1) acquisition of research competences \\
\hline 11 & 25 & $\mathrm{w}$ & $\begin{array}{l}\text { Medical student and doctoral } \\
\text { candidate }\end{array}$ & - & $\begin{array}{l}\text { 1) customariness, 2) research } \\
\text { interest and research competence } \\
\text { development }\end{array}$ & yes & $\begin{array}{l}\text { 1) obtaining title/prestige } \\
\text { 2) other: pride }\end{array}$ \\
\hline 12 & 22 & $\mathrm{~m}$ & $\begin{array}{l}\text { Medical student and doctoral } \\
\text { candidate }\end{array}$ & - & $\begin{array}{l}\text { 1) prestige, 2) improve career } \\
\text { opportunities }\end{array}$ & yes & 1) general skills and personality development \\
\hline 13 & 22 & $\mathrm{w}$ & $\begin{array}{l}\text { Medical student and doctoral } \\
\text { candidate }\end{array}$ & - & $\begin{array}{l}\text { 1) research interest and research } \\
\text { competence development } \\
\text { 2) customariness, 3) prestige } \\
24\end{array}$ & yes & 1) general skills and personality development \\
\hline
\end{tabular}




\begin{tabular}{|c|c|c|c|c|c|c|c|}
\hline ID & Age & Gender & Occupation & $\begin{array}{l}\text { Amount of } \\
\text { Research }\end{array}$ & Motives to obtain a doctorate & $\begin{array}{l}\text { Meaningful } \\
\text { /Sensible }\end{array}$ & Justification of meaningfulness \\
\hline 14 & 23 & $\mathrm{~m}$ & $\begin{array}{l}\text { Medical student and doctoral } \\
\text { candidate }\end{array}$ & - & $\begin{array}{l}\text { 1) research interest and research } \\
\text { competence development }\end{array}$ & yes & $\begin{array}{l}\text { 1) general skills and personality developmen } \\
\text { 2) acquisition of research competences }\end{array}$ \\
\hline
\end{tabular}

\section{Life Sciences}

\begin{tabular}{|c|c|c|c|c|c|c|c|}
\hline 1 & k. A. & $\mathrm{m}$ & Academic research & $100 \%$ & $\begin{array}{l}\text { 1) (option of) research career } \\
\text { 2) preventing job disadvantages }\end{array}$ & yes & $\begin{array}{l}\text { 1) career outside of research, 2) research } \\
\text { career/engaging in research activities, } \\
\text { 3) prestige }\end{array}$ \\
\hline 2 & 29 & $\mathrm{f}$ & $\begin{array}{l}\text { Project manager in industrial } \\
\text { research }\end{array}$ & - & $\begin{array}{l}\text { 1) research interest and research } \\
\text { competence development } \\
\text { 2) preventing job disadvantages }\end{array}$ & yes & $\begin{array}{l}\text { 1) acquisition of research competences } \\
\text { 2) general skills and personality development }\end{array}$ \\
\hline 3 & 30 & $\mathrm{~m}$ & Academic research & $50 \%$ & $\begin{array}{l}\text { 1) preventing job disadvantages } \\
\text { 2) opportunities }\end{array}$ & ambivalent & $\begin{array}{l}\text { 1) research career/engaging in research } \\
\text { activities, 2) career outside of research (in } \\
\text { future) }\end{array}$ \\
\hline 5 & 33 & $\mathrm{f}$ & Industrial research & $\begin{array}{l}\text { Research and } \\
\text { development }\end{array}$ & $\begin{array}{l}\text { 1) research interest and research } \\
\text { competence development, } \\
\text { 2) (option of) research career }\end{array}$ & yes & 1) career outside of research \\
\hline 6 & 34 & $\mathrm{~m}$ & Academic research & $100 \%$ & $\begin{array}{l}\text { 1) research interest and research } \\
\text { competence development, } \\
\text { 2) improve career opportunities }\end{array}$ & yes & $\begin{array}{l}\text { 1) general skills and personality development } \\
\text { 2) general career prospects }\end{array}$ \\
\hline 7 & 34 & $\mathrm{f}$ & Scientific publisher & - & $\begin{array}{l}\text { 1) research interest and research } \\
\text { competence development, 2) } \\
\text { (option of) research career, } \\
\text { 3) customariness, } \\
\text { 4) improve career opportunities }\end{array}$ & yes & 1) general career prospects \\
\hline 8 & 33 & $\mathrm{~m}$ & Academic research & $100 \%$ & $\begin{array}{l}\text { 1) research interest and research } \\
\text { competence development, } \\
\text { 2) preventing job disadvantages }\end{array}$ & yes & $\begin{array}{l}\text { 1) general skills and personality development } \\
\text { 2) acquisition of research competences }\end{array}$ \\
\hline 9 & 33 & $\mathrm{~m}$ & Academic research & $100 \%$ & 1) preventing job disadvantages & yes & $\begin{array}{l}\text { 1) general skills and personality development } \\
\text { 2) acquisition of research competences }\end{array}$ \\
\hline 10 & 28 & $\mathrm{f}$ & Academic research & $100 \%$ & $\begin{array}{l}\text { 1) research interest and research } \\
\text { competence development }\end{array}$ & yes & 1) research career/engaging in research activities \\
\hline
\end{tabular}




\begin{tabular}{|c|c|c|c|c|c|c|c|}
\hline ID & Age & Gender & Occupation & $\begin{array}{l}\text { Amount of } \\
\text { Research }\end{array}$ & Motives to obtain a doctorate & $\begin{array}{l}\text { Meaningful } \\
\text { /Sensible }\end{array}$ & Justification of meaningfulness \\
\hline 11 & 29 & f & $\begin{array}{l}\text { Project manager in industrial } \\
\text { research }\end{array}$ & - & $\begin{array}{l}\text { 1) preventing job disadvantages } \\
\text { 2) given opportunities }\end{array}$ & yes & $\begin{array}{l}\text { 1) prestige, 2) general skills and personality } \\
\text { development }\end{array}$ \\
\hline 12 & 31 & $\mathrm{~m}$ & $\begin{array}{l}\text { Software engineer, industrial } \\
\text { research }\end{array}$ & $\begin{array}{l}\text { Research } \\
\text { related } \\
\text { activities }\end{array}$ & $\begin{array}{l}\text { 1) customariness, } \\
\text { 2) prestige, 3) preventing job } \\
\text { disadvantages }\end{array}$ & yes & $\begin{array}{l}\text { 1) general skills and personality development, 2) } \\
\text { general career prospects }\end{array}$ \\
\hline 13 & 32 & $\mathrm{f}$ & $\begin{array}{l}\text { Project manager in industrial } \\
\text { research }\end{array}$ & - & $\begin{array}{l}\text { 1) preventing job disadvantages, } \\
\text { 2) (option of) research career }\end{array}$ & ambivalent & 1) obtaining title/prestige \\
\hline 14 & 28 & $\mathrm{f}$ & Academic research & $100 \%$ & $\begin{array}{l}\text { 1) given opportunities, } \\
\text { 2) (option of) research career }\end{array}$ & yes & $\begin{array}{l}\text { 1) acquisition of research competences, } 2 \text { ) } \\
\text { research career/engaging in research activities }\end{array}$ \\
\hline
\end{tabular}

Legend: all characteristics refer to the time of the interview, $\mathrm{m}=$ male, $\mathrm{f}=\mathrm{female}$ 
Table A2: Coding Scheme

\begin{tabular}{|c|c|c|c|}
\hline Main Categories & Subcategories & Medicine (N) & Life Sciences (N) \\
\hline \multirow{7}{*}{$\begin{array}{l}\text { Motives to obtain } \\
\text { doctorate }\end{array}$} & $\begin{array}{l}\text { Research interest and research competence } \\
\text { development }\end{array}$ & & $6 / 14$ \\
\hline & (Option of) a research career & $7 / 13$ & $6 / 14$ \\
\hline & Customariness & $5 / 13$ & $2 / 14$ \\
\hline & Preventing job disadvantages & & $9 / 14$ \\
\hline & Improve career opportunities & $5 / 13$ & $2 / 14$ \\
\hline & Prestige & $5 / 13$ & $1 / 14$ \\
\hline & Given opportunities & & $2 / 14$ \\
\hline \multirow{2}{*}{$\begin{array}{l}\text { Doctorate } \\
\text { meaningful/ } \\
\text { sensible? }\end{array}$} & ambivalent & $2 / 13$ & $2 / 14$ \\
\hline & yes & $11 / 13$ & $12 / 14$ \\
\hline \multirow{8}{*}{$\begin{array}{l}\text { Justification of } \\
\text { meaningfulness }\end{array}$} & general skills and personality development & $6 / 13$ & $6 / 14$ \\
\hline & Obtaining title/ prestige & $2 / 13$ & $2 / 14$ \\
\hline & Acquisition of research competences & $4 / 13$ & $3 / 14$ \\
\hline & Career outside of research & & $3 / 14$ \\
\hline & $\begin{array}{l}\text { Career orientation/ exclusion of research } \\
\text { career }\end{array}$ & $2 / 13$ & \\
\hline & $\begin{array}{l}\text { Research career/engaging in research } \\
\text { activities }\end{array}$ & $2 / 13$ & $5 / 14$ \\
\hline & General career prospects & & $4 / 14$ \\
\hline & Pride (felt for achievement of doctorate) & $2 / 13$ & \\
\hline
\end{tabular}

Legend: overview of coding scheme with absolute frequencies by subject area

Tab. A3: Overview of Quantitative Item Battery, Motives to Obtain Doctorate

I wanted to obtain a doctorate...

E-Prom Study

because it is very customary in my subject

to afterwards work in industrial research

to afterwards work in research (generally)

to gain subject specific knowledge

to research during the doctorate

in order to intensely engagement with the topic of the doctorate

to lead a researcher's lifestyle

to improve my career opportunities

to achieve a higher income

in order to not having to commit to a profession yet

due to a lack of alternatives

to flexibly arrange my work and free time

in order to have a good work-life balance during the doctorate

because I was encouraged by other persons

it turned out that way

MediBAS Study

because it is very customary in my subject

to avoid disadvantages on the labor market

to afterwards work in research (generally)

to gain subject specific knowledge 
to research during the doctorate

in order to intensely engagement with the topic of the doctorate

to keep the option of a research career open to myself

to better practice evidenced-based medicine

to achieve a higher income

to achieve a higher societal reputation

to achieve a higher reputation in the eyes of patients

to achieve a higher reputation in the eyes of colleagues

Legend: original items in German, here freely translated by the

authors. Items are assessed on 5 point Likert scale and introduced by the sentence ,I wanted to obtain a doctorate... “ 


\section{Figures}

To work in research after the doctorate

Keep the option of research career open

To research during the doctorate

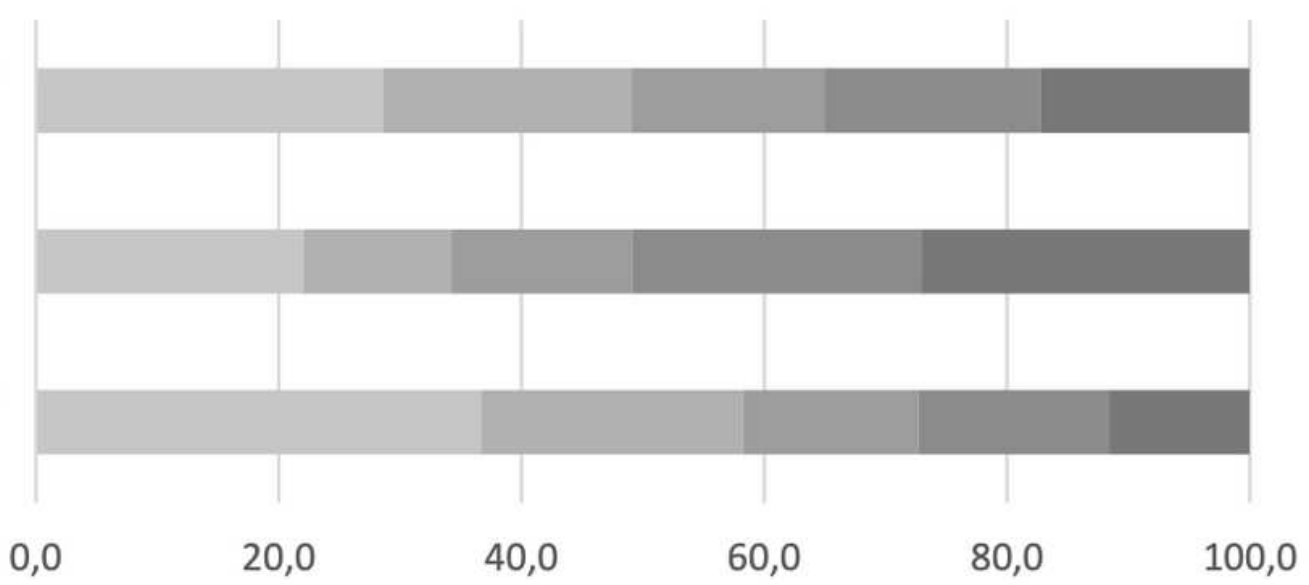

1. compeletly disagree

2. rather disagree

3. neither agree nor disagree

4. rather agree

\section{Figure 1}

Research Interest When Chosing the Doctorate

5. completely agree

4. rather agree

3. neither agree nor disagree

2. rather disagree

1. compeletly disagree

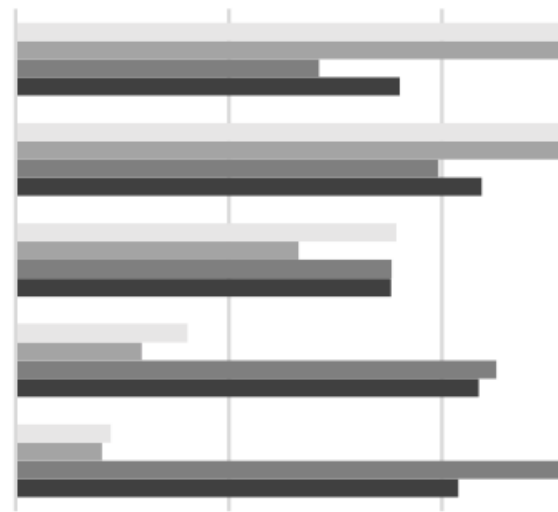

0
LS: To work in research after the doctorate

M:To work in research after the doctorate
LS: To research during the doctorate M: To research during the doctorate

\section{Figure 2}

Research Interest When Choosing to Obtain a Doctorate, Medicine (M) and Life Sciences (LS) 